GRASAS Y ACEITES 69 (4)

October-December 2018, e271

ISSN-L: 0017-3495

https://doi.org/10.3989/gya.0104181

\title{
Elliptic Fourier based analysis and multivariate approaches for size and shape distinctions of walnut (Juglans regia L.) cultivars
}

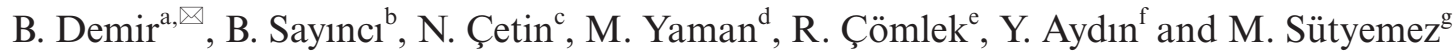 \\ ${ }^{a}$ Department of Mechanical and Metal Technologies, Vocational School of Technical Sciences, \\ Mersin University, 33343, Çiftlikköy Campus, Yenişehir, Mersin, Turkey \\ ${ }^{\mathrm{b}}$ Department of Agricultural Machinery and Technologies Engineering, \\ Faculty of Agriculture, Atatürk University, 25240, Erzurum, Turkey \\ ${ }^{c}$ Department of Biosystem Engineering, Faculty of Agriculture, Erciyes University, 38039, Kayseri, Turkey \\ ${ }^{\mathrm{d} D}$ Department of Horticulture, Faculty of Agriculture, Erciyes University, 38039, Kayseri, Turkey \\ e,f Department of Agricultural Machinery, Graduate School of Natural \\ and Applied Science, Atatürk University, 25240, Erzurum, Turkey \\ ${ }^{\mathrm{g}}$ Department of Horticulture, Faculty of Agriculture, Kahramanmaras Sütçü İmam University, 46040, \\ Kahramanmaraş, Turkey \\ ${ }^{\bowtie}$ Corresponding author: bd@mersin.edu.tr
}

Submitted: 11 January 2018; Accepted: 22 May 2018

SUMMARY: Size and shape data of agricultural crops provide great sources for food processing technologies. The physical attributes of different fruits should be known for the design, developing and innovation of food technologies. In this study, the size and shape distinctions of fifteen national and international walnut cultivars (Midland, Sütyemez-1, Serr, Maraş-18, Maraş-12, Sütyemez-2, Kaman-1, Kaman-5, Pedro, Howard, Chandler, Şebin, Şen-2, Bilecik and KR-1) were determined using elliptic Fourier and multivariate approaches. Firstly, the gravitational features of walnut cultivars were determined, and their dimensional, area and shape attributes were revealed by image processing. Cluster analysis was used to designate the walnut cultivars. Elliptic Fourier descriptors obtained from walnut outlines provided the comparisons among walnut cultivars in shape. The shape index indicated that Serr, Sütyemez-2, Midland and Şen-2 cultivars were oval-shaped, and the others were spherical. The cluster analysis divided the walnut cultivars into four subgroups. Elliptic Fourier descriptors perfectly distinguished the walnut cultivars according to shape.

KEYWORDS: Dimensional analysis; Image processing; Physical attribute; Projected area; Shape descriptor; Shape index

RESUMEN: Análisis mediante elíptica de Fourier y multivariante para diferenciar tamaño y forma de cultivos de nogal (Juglans regia $L$.). Los datos de tamaño y forma de los cultivos agrícolas proporcionan grandes fuentes para las tecnologías de procesamiento de alimentos. Los atributos físicos de diferentes frutas deben conocerse para el diseño, desarrollo e innovación de tecnologías alimentarias. En este estudio, las diferencias de tamaño y forma de quince cultivares de nueces nacionales e internacionales (Midland, Sütyemez-1, Serr, Maraş-18, Maraş-12, Sütyemez-2, Kaman-1, Kaman-5, Pedro, Howard, Chandler, Şebin, Şen-2, Bilecik y KR-1) se realizaron mediante elípticas de Fourier y multivariantes. En primer lugar, se determinaron las características gravitacionales de los cultivares de nogal, y sus atributos dimensionales de área y de forma se revelaron mediante el procesamiento de imágenes. El análisis de clusters se utilizó para designar los cultivares de nueces. Los descriptores de elípticas de Fourier obtenidos a partir de contornos de nogal proporcionaron las comparaciones de formas entre los cultivares de nueces. El índice de forma indicó que los cultivares Serr, Sütyemez-2, Midland y Şen-2 tenían forma ovalada, y los otros eran esféricos. El análisis de conglomerados dividió los cultivares de nueces en cuatro subgrupos. Los descriptores de elípticas de Fourier distinguían de manera excelente las formas de las variedades de nueces.

PALABRAS CLAVE: Análisis dimensional; Área proyectada; Atributo físico; Descriptor de forma; Índice de forma; Procesamiento de imágenes

ORCID ID: Demir B https://orcid.org/0000-0002-6405-4724, Sayınc1 B https://orcid.org/0000-0001-7148-0855, Cetin N https://orcid.org/0000-0001-8524-8272, Yaman Mhttps://orcid.org/0000-0002-2899-2238, Çömlek R https://orcid.org/00000002-2240-4343, Aydın Y https://orcid.org/0000-0003-3952-9932, Sütyemez M https://orcid.org/0000-0003-2417-8009

Citation/Cómo citar este artículo: Demir B, Sayıncı B, Çetin N, Yaman M, Çömlek R, Aydın Y, Sütyemez M. 2018. Elliptic Fourier based analysis and multivariate approaches for size and shape distinctions of walnut (Juglans regia L.) cultivars. Grasas Aceites $\mathbf{6 9}$ (4), e271. https://doi.org/10.3989/gya.0104181

Copyright: (02018 CSIC. This is an open-access article distributed under the terms of the Creative Commons Attribution 4.0 International (CC BY 4.0) License. 


\section{INTRODUCTION}

Turkey is the oldest walnut (Juglans regia L.) growing country and is accepted as one of the primary gene centers for walnuts (Bayazit et al., 2007). There are 21 species of Juglans known worldwide up to now. Among the species, Juglans regia (L), with a great commercial value, is expanding to a great deal of the regions all over the world and is the most popular one. Walnuts have quite diverse features and attributes and all these differences are mostly originated from the genetic structure of the seeds used in the walnut culture (Şen and Tekintaş, 1992).

FAO (2014) resources showed that Turkey was the fourth largest walnut producer in the world after China, the United States and Iran, and the annual walnut production of Turkey was reported as 180.807 tones. Walnut fruits are quite rich in oils $(56.4 \%-70.6 \%)$ and proteins $(13.6 \%-22.3 \%)$. Therefore, walnuts are considered as a significant source of nutrition and suggested as a dietary nutrient against cardiovascular diseases. Walnut fruits are also rich in vitamin A, group B vitamins (thiamin$\mathrm{B} 1$, riboflavin-B2, niacin-B6) and minerals $(\mathrm{P}, \mathrm{K}$, $\mathrm{Mg}, \mathrm{Fe}, \mathrm{Na}$ and $\mathrm{Ca}$ ) (Sahin and Akbaș, 2001; Patel, 2005; Cosmulescu et al., 2009).

The physical features, especially the visual appearance of agricultural products, are significant engineering parameters. These features are composed of size and shape attributes (dimensions, area, gravitational, elongation, roundness and spherical parameters). In order to design a processing system or develop a method for processing of any agricultural product, these descriptive variables should be known. In addition, the physical attributes of a product play a great role in designing postharvest processes or industrial purposes such as handling, storage, sizing, fracturing, classifying, packaging, drying and transportation (Sadrnia et al., 2007; Sun et al., 2012; Sayinci et al., 2012). The size and shape attributes of any product are essential descriptive data used to identify plant cultivars, assess marketing quality, analyze shape abnormalities and investigate the heritability of the product (Brewer et al., 2007; Costa et al., 2011).

Several studies have been conducted about the physical attributes of different fruit species and cultivars and the results and outcomes of these studies yielded a crucial database for the physical attributes of the fruits. Such studies involve size and shape attributes of different fruit species or genotypes such as orange (Sayinci et al., 2012), walnut (Ozkan and Koyuncu 2005; Ercisli et al., 2012), bean (Kara et al., 2013), cherry laurel (Sayinc1 et al., 2015b), hazelnut (Sayinc1 et al., 2015a), strawberry (Liming and Yanchao 2010), almond (Antonucci et al., 2012), pistachio (Ghazanfari et al., 1997) and loquat (Boydas et al., 2012).
As indicated by some researchers (Costa et al., 2011; Antonucci et al., 2012; Sun et al., 2012), there are disharmonies among different semantic or visual evaluations used for shape description. While shape descriptions such as elongation, roundness, circularity and symmetry were used for classifying or identifying agricultural products, Sayınc1 et al., (2015a) reported that these descriptors were not able to distinguish the cultivars sufficiently. Instead of semantic or visual descriptions, most of the researchers applied the Elliptic Fourier Analysis (EFA), using shape descriptors for the shape analysis of agricultural products such as cereal grains (Mebatsion et al., 2012), hazelnut (Sayınc1 et al., 2015a), orange (Costa et al., 2009), apple (Currie et al., 2000) and almond (Antonucci et al. 2012). EFA using shape descriptors dissociates the boundary contour of a fruit into a set of harmonically closed curves and at the end of the set the original outline of the fruit view is generated (Costa et al., 2011). The EFA method is widely used to determine the shape discrimination among cultivars.

The aim of this study was to contribute to the walnut database involving size and shape attributes of walnut cultivars, to comprise data required for the design of walnut processing systems and to reveal distinctions among fifteen different walnut cultivars in terms of shape attributes by means of Elliptic Fourier descriptors using an image processing operation.

\section{MATERIALS AND METHODS}

\subsection{Sample preparation}

In this study, 5 international (Midland, Serr, Pedro, Howard and Chandler) and 10 national walnut (Juglans regia L.) cultivars (Sütyemez-1, Maraş18, Maraş-12, Sütyemez-2, Kaman-1, Kaman-5, Şebin, Şen-2, Bilecik and KR-1) were used as the plant material (Table 1). The walnut cultivars were provided from the Nuts Research and Application Center of Kahramanmaraş Sütçü İmam University in the Kahramanmaraş province of Turkey.

\subsection{Image acquisition system}

In order to reveal the size and shape attributes of walnut cultivars, an imaging system, details of which were explained by Kara et al., (2013), consisting of a digital camera (Nikon D300, JP) and illumination equipment (paraflashes with softbox) was used. The digital images of the walnut cultivars were taken in a dark room. The camera was fixed on a frame in a position perpendicular to a whitecolored fiberglass surface at a constant height of $50.5 \mathrm{~cm}$. The walnut samples were kept in a fridge $\left(-4{ }^{\circ} \mathrm{C}\right)$ until subsequent analyses. For each of the cultivars, 100 samples were randomly selected from a box where they were kept. Firstly, a digital balance 
TABLE 1. Walnut cultivars at horizontal and vertical orientations

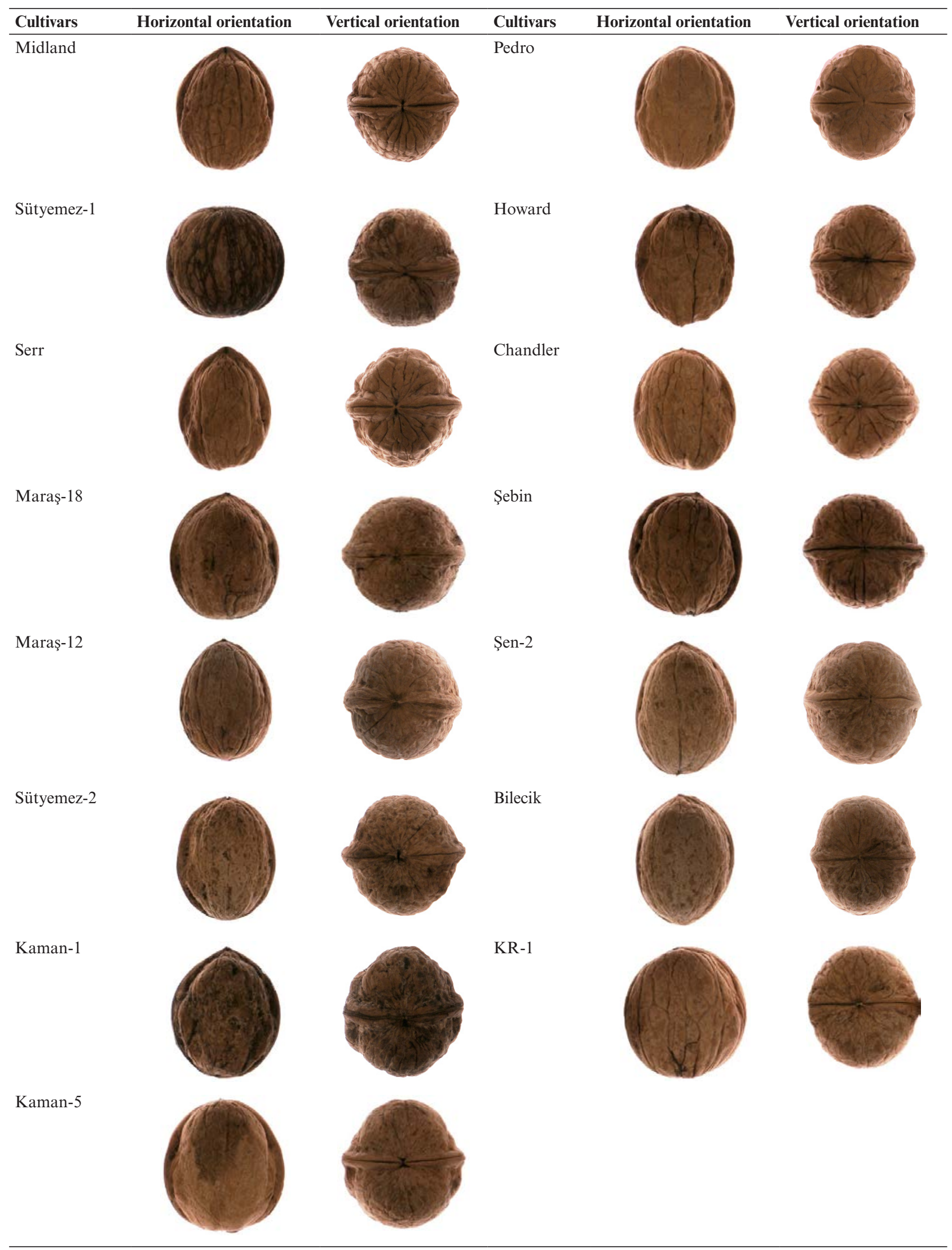


(Shimadzu TW423L Model, JP) ( $\pm 0.001 \mathrm{~g})$ was used to determine fruit mass. After that, the walnut samples were placed on a transparent fiberglass plate in a matrix form of $3 \times 6$ at two orientations, namely horizontal and vertical. Putty was used to position the walnuts on the fiberglass plates. A ruler on the fiberglass surface centered at the bottom of the image area surface was used to convert the unit from pixel to millimeter. The conversion ratio was found as $15.54-$ pixel $\cdot \mathrm{mm}^{-1}$. A cable release was used to prevent vibration during the imaging. For the moisture content of the walnut samples used in present study, 20 samples randomly selected from each cultivar were dried at $105^{\circ} \mathrm{C}$ for 24 hours and their mass was measured again. The images captured by the camera were saved as a color *.tiff extension image files for descriptive analysis and *.bmp extension image files for the EFA. During the experiments, mean temperature and relative humidity of the laboratory were recorded as $24.0^{\circ} \mathrm{C}$ and $24 \%$, respectively.

\subsection{Descriptive variables of walnut cultivars}

SigmaScan ${ }^{\circledR}$ Pro 5.0 software was used in order to process the walnut images, and projected area, perimeter, length, width, thickness, maximum and minimum diameters and aspect ratio variables were determined for each walnut at horizontal and vertical orientations by means of the image processing operation (Figure 1). The variables of shape index, geometric mean diameter, surface area, sphericity and volume were calculated using the equations given in Table 2. A shape index of lower than 1.25 was considered as spherical and a value over 1.25 was considered as oval (Ozkan and Koyuncu, 2005).

\subsection{Shape analysis based on Elliptic Fourier Analysis}

The walnut images were saved as color bitmap image files for the EFA. The aim of the EFA was to reveal the shape variation among the walnut cultivars. For this purpose, the outlines of each walnut image were firstly digitized using SHAPE version 1.3 software (Iwata and Ukai 2002). All data were

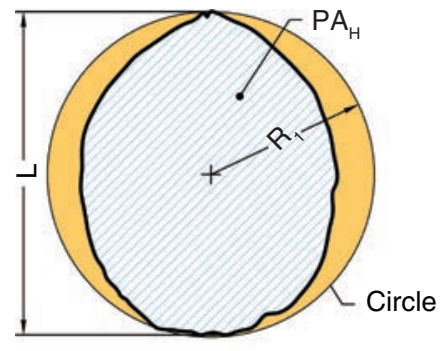

Horizontal orientation

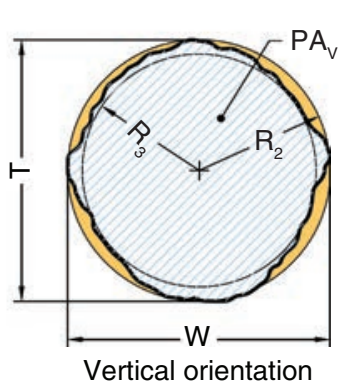

FIGURE 1. Imaging orientations and dimensions of walnut samples
TABLE 2. Equations used to calculate the size and shape attributes of walnut cultivars

\begin{tabular}{lcl}
\hline Variables & \multicolumn{1}{c}{ Equations* } & Literatures \\
\hline Shape index $(S I)$ & $S I=(2 \cdot L) /(W+T)$ & $\begin{array}{l}\text { Ozkan and } \\
\text { Koyuncu }(2005)\end{array}$ \\
$\begin{array}{l}\text { Geom. mean } \\
\text { diameter }\left(D_{g}, \mathrm{~mm}\right)\end{array}$ & $D_{g}=(L \cdot W \cdot T)^{(1 / 3)}$ & $\begin{array}{l}\text { Mohsenin } \\
(1986)\end{array}$ \\
$\begin{array}{l}\text { Surface area } \\
\left(S, \mathrm{~mm}^{2}\right)\end{array}$ & $\mathrm{S}=\pi \cdot D_{g}^{2}$ & $\begin{array}{l}\text { Sayinci } \text { et al. } \\
(2015 \mathrm{a})\end{array}$ \\
$\begin{array}{l}\text { Sphericity }(\varphi, \%) \\
\text { Volume }\left(V, \mathrm{~cm}^{3}\right)\end{array}$ & $\varphi=\left(D_{g} / L\right) \cdot 100$ & $\begin{array}{l}\text { Mohsenin } \\
(1986)\end{array}$ \\
& & $\begin{array}{l}\text { Volume of } \\
\text { ellipse }\end{array}$ \\
\hline
\end{tabular}

* $L$ : length $(\mathrm{mm}) ; W$ : width $(\mathrm{mm}) ; T$ : thickness $(\mathrm{mm}) ; D_{g}$ : geometric mean diameter $(\mathrm{mm}) ; R_{l}$ : maximum diameter at horizontal orientation $(\mathrm{cm}) ; R_{2}$ : maximum diameter at width orientation $(\mathrm{cm}) ; R_{3}$ : minimum diameter at width orientation $(\mathrm{cm})$

recorded as chain codes to describe the geometrical information about outlines ranging from $0-7$. The data obtained from the chain code were normalized using a module of the software based on the ellipse of the first harmonic in order to be independent from orientation, size, or location. In order to describe the outlines of walnut samples, 20 harmonic numbers were used (Iwata and Ukai 2002; Mebatsion et al., 2012; Vasallo et al., 2013).

\subsection{Statistical analysis}

In this study, approximately 100 walnuts of each cultivar, totaling 1492 walnut samples were used, and their mass, volume, length, width, thickness, geometric mean diameter, surface area, sphericity, shape index values, and projected area, perimeter and aspect ratio values at two orientations were determined as descriptive variables. A correlation matrix created for descriptive data showed the relationships among the variables. The resultant data were subjected to analysis of variance (ANOVA) with a 95\% confidence level using SPSS version 20. Differences among the means were determined with Tukey's comparison test at 5\% significance level. In reference to the descriptive variables of walnut cultivars, similar cultivars were determined using a hierarchical cluster analysis. For this analysis, Ward's method algorithm was used. The cluster analysis was performed by using the squared Euclidean distance method with arithmetic averages of walnut cultivars.

Shape descriptors obtained from EFA were also used to perform principle component analysis (PCA) based on the variance-covariance matrix. The resulting PC scores for each walnut cultivar were used as observed values of shape features. MANOVA was carried out using PAST version 3.01 (Hammer et al., 2001). Wilks' Lambda and Pillai trace values 
and $p$ values were determined. The matrix of differences among walnut cultivars was obtained from Hotelling's pairwise comparisons with Bonferroni correction and squared Mahalanobis distances which make two-cultivar comparisons possible. Differences in walnut outlines were evaluated using a discriminant analysis (Sayinci et al., 2015a). Group centroids of walnut cultivars obtained from discriminant analysis were presented in a scatter plot with canonical discrimination functions.

\section{RESULTS}

\subsection{Relationships among variables describing walnut cultivars}

The correlation matrix is provided in Table 3. Correlation greater than 0.70 were marked. While correlations between mass $(M)$ and the other variables were not found to be significant, volume $(V)$ significantly correlated with the area variables $(S A$, $P A_{h}$ and $P H_{v}$ ) of the walnut cultivars. Similarly, the correlations between length and the other dimensional variables $\left(W, T, D_{g}, P_{h}\right.$ and $\left.P_{v}\right)$ were not found to be significant. As for the descriptive shape attributes of the walnut cultivars, sphericity and shape index showed a significant negative correlation. The correlations between aspect ratio variables measured at horizontal and vertical orientations $\left(A R_{h}\right.$ and $\left.A R_{v}\right)$ were not found to be significant.

\subsection{Gravitational and area attributes}

The mass, volume, surface area and projected area averages are provided in Table 4 . While the KR-1 cultivar had the highest gravitational and area averages, the lowest averages were observed for the Serr and Maraş-12 cultivars. Surface area to volume ratio averages varied between 1.42 and 1.89 and the ratio decreased with increasing volumes. Projected area values at two orientations positively correlated with the volume values of the walnuts. However, the projected area averages of the walnut cultivars at two orientations were significantly different. The lowest projected area ratio was observed for the KR-1 and Sütyemez-1 cultivars. The projected area averages measured at the horizontal orientation of the Sütyemez-2 and Serr cultivars were significantly higher than those of vertical orientation. This ratio was considerably close to 1.00 for the KR-1 and Sütyemez-1 cultivars.

\subsection{Dimensional attributes}

The dimensional attributes of the walnut cultivars are provided in Table 5. While the KR-1 and Şen-2 cultivars had the longest dimensions, the Maraş-12 cultivar had the lowest length average. As the width of the walnuts increased, the other dimensional attributes $\left(T, D_{g}, P_{h}\right.$ and $\left.P_{v}\right)$ also increased because of the positive correlations among size variables, except for length. As seen from the averages,

TABLE 3. Correlation matrix for size, shape and gravitational variables

\begin{tabular}{|c|c|c|c|c|c|c|c|c|c|c|c|c|c|c|c|}
\hline Variables ${ }^{1}$ & $\begin{array}{c}M \\
(\mathrm{~g})\end{array}$ & $\begin{array}{c}V \\
\left(\mathrm{~cm}^{3}\right)\end{array}$ & $\begin{array}{c}P A_{h} \\
\left(\mathbf{m m}^{2}\right)\end{array}$ & $\begin{array}{c}P A_{v} \\
\left(\mathbf{m m}^{2}\right)\end{array}$ & $\begin{array}{c}S A \\
\left(\mathrm{~cm}^{2}\right)\end{array}$ & $\underset{(\mathrm{mm})}{L}$ & $\begin{array}{c}W \\
(\mathbf{m m})\end{array}$ & $\begin{array}{c}T \\
(\mathbf{m m})\end{array}$ & $\begin{array}{c}D_{g} \\
(\mathbf{m m})\end{array}$ & $\begin{array}{c}\boldsymbol{P}_{h} \\
(\mathbf{m m})\end{array}$ & $\begin{array}{c}\boldsymbol{P}_{v} \\
(\mathbf{m m})\end{array}$ & $\underset{(\%)}{S}$ & $S I$ & $A \boldsymbol{R}_{h}$ & $\boldsymbol{A} \boldsymbol{R}_{v}$ \\
\hline$M(\mathrm{~g})$ & 1 & 0.552 & 0.495 & 0.551 & 0.560 & 0.446 & 0.528 & 0.531 & 0.562 & 0.493 & 0.553 & 0.068 & -0.084 & 0.011 & 0.015 \\
\hline$V\left(\mathrm{~cm}^{3}\right)$ & 0.552 & 1 & 0.904 & 0.951 & 0.990 & 0.820 & 0.906 & 0.895 & 0.977 & 0.888 & 0.932 & 0.024 & -0.041 & 0.027 & 0.022 \\
\hline$P A_{h}\left(\mathrm{~mm}^{2}\right)$ & 0.495 & 0.904 & 1 & 0.799 & 0.914 & 0.920 & 0.750 & 0.771 & 0.911 & 0.992 & 0.794 & -0.238 & 0.230 & 0.034 & -0.051 \\
\hline$P A_{v}\left(\mathrm{~mm}^{2}\right)$ & 0.551 & 0.951 & 0.799 & 1 & 0.952 & 0.652 & 0.946 & 0.944 & 0.945 & 0.778 & 0.988 & 0.265 & -0.274 & -0.162 & 0.033 \\
\hline$S A\left(\mathrm{~cm}^{2}\right)$ & 0.560 & 0.990 & 0.914 & 0.952 & 1 & 0.839 & 0.918 & 0.914 & 0.996 & 0.905 & 0.948 & 0.02 & -0.038 & 0.032 & 0.024 \\
\hline$L(\mathrm{~mm})$ & 0.446 & 0.820 & 0.920 & 0.652 & 0.839 & 1 & 0.627 & 0.625 & 0.842 & 0.941 & 0.656 & -0.486 & 0.471 & 0.381 & 0.014 \\
\hline$W(\mathrm{~mm})$ & 0.528 & 0.906 & 0.750 & 0.946 & 0.918 & 0.627 & 1 & 0.847 & 0.920 & 0.739 & 0.957 & 0.276 & -0.282 & -0.125 & 0.267 \\
\hline$T(\mathrm{~mm})$ & 0.531 & 0.895 & 0.771 & 0.944 & 0.914 & 0.625 & 0.847 & 1 & 0.920 & 0.756 & 0.944 & 0.287 & -0.304 & -0.198 & -0.221 \\
\hline$D_{g}(\mathrm{~mm})$ & 0.562 & 0.977 & 0.911 & 0.945 & 0.996 & 0.842 & 0.920 & 0.920 & 1 & 0.909 & 0.951 & 0.025 & -0.042 & 0.028 & 0.022 \\
\hline$P_{h}(\mathrm{~mm})$ & 0.493 & 0.888 & 0.992 & 0.778 & 0.905 & 0.941 & 0.739 & 0.756 & 0.909 & 1 & 0.781 & -0.278 & 0.271 & 0.088 & -0.040 \\
\hline$P_{v}(\mathrm{~mm})$ & 0.553 & 0.932 & 0.794 & 0.988 & 0.948 & 0.656 & 0.957 & 0.944 & 0.951 & 0.781 & 1 & 0.273 & -0.285 & -0.162 & 0.054 \\
\hline$S(\%)$ & 0.068 & 0.024 & -0.238 & 0.265 & 0.020 & -0.486 & 0.276 & 0.287 & 0.025 & -0.278 & 0.273 & 1 & -0.951 & -0.651 & -0.009 \\
\hline$S I$ & -0.084 & -0.041 & 0.230 & -0.274 & -0.038 & 0.471 & -0.282 & -0.304 & -0.042 & 0.271 & -0.285 & -0.951 & 1 & 0.614 & 0.020 \\
\hline$A P_{h}$ & 0.011 & 0.027 & 0.034 & -0.162 & 0.032 & 0.381 & -0.125 & -0.198 & 0.028 & 0.088 & -0.162 & -0.651 & 0.614 & 1 & 0.190 \\
\hline$A R_{\mathrm{v}}$ & 0.015 & 0.022 & -0.051 & 0.033 & 0.024 & 0.014 & 0.267 & -0.221 & 0.022 & -0.040 & 0.054 & -0.009 & 0.020 & 0.190 & 1 \\
\hline
\end{tabular}

${ }^{1} M$ : mass; $V$ : volume; $P A_{h}$ : projected area at horizontal orientation; $P A_{v}$ : projected area at vertical orientation; $S A$ : surface area; $L$ : length; $W$ : width; $T$ : thickness; $D_{g}$ : geometric mean diameter; $P_{h}$ : perimeter at horizontal orientation; $P_{v}$ : perimeter at vertical orientation; $S$ : sphericity; $S I$ : shape index; $A R_{h}$ : aspect ratio at horizontal orientation; $A R_{v}$ : aspect ratio at vertical orientation 


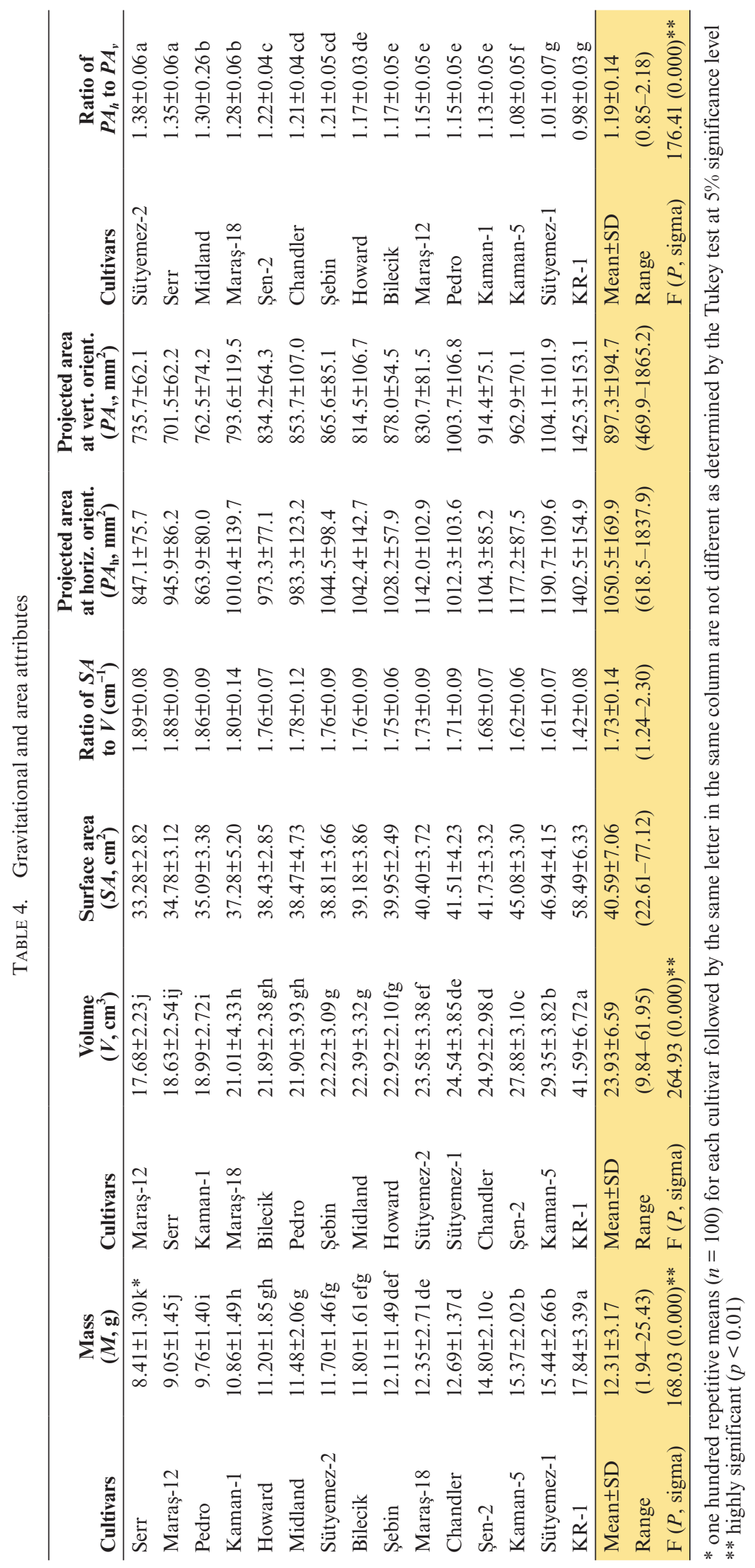


TABLE 5. Dimensional attributes

\begin{tabular}{llllcccc}
\hline Cultivars & \multicolumn{1}{c}{$\begin{array}{c}\text { Length } \\
(\boldsymbol{L}, \mathbf{m m})\end{array}$} & Cultivars & $\begin{array}{c}\text { Width } \\
(\boldsymbol{W}, \mathbf{m m})\end{array}$ & $\begin{array}{c}\text { Thickness } \\
(\boldsymbol{T}, \mathbf{m m})\end{array}$ & $\begin{array}{c}\text { Geometric } \\
\text { mean diam. } \\
\left(\boldsymbol{D}_{\boldsymbol{g}}, \mathbf{m m}\right)\end{array}$ & $\begin{array}{c}\text { Perimeter at } \\
\text { horiz.orient. } \\
\left(\boldsymbol{P}_{\boldsymbol{h}}, \mathbf{m m}\right)\end{array}$ & $\begin{array}{c}\text { Perimeter at } \\
\text { vert. orient. } \\
\left(\boldsymbol{P}_{\boldsymbol{v}}, \mathbf{m m}\right)\end{array}$ \\
\hline Maraş-12 & $36.7 \pm 1.9 \mathrm{j}^{*}$ & Maraş-12 & $32.1 \pm 1.5 \mathrm{k}$ & $29.2 \pm 1.2$ & $32.5 \pm 1.4$ & $104.2 \pm 4.7$ & $97.3 \pm 4.1$ \\
Sütyemez-1 & $37.4 \pm 2.4 \mathrm{i}$ & Serr & $32.2 \pm 1.4 \mathrm{k}$ & $28.3 \pm 1.4$ & $33.3 \pm 1.5$ & $110.9 \pm 5.3$ & $97.0 \pm 4.2$ \\
Kaman-1 & $37.5 \pm 2.0 \mathrm{i}$ & Kaman-1 & $33.2 \pm 1.7 \mathrm{j}$ & $29.9 \pm 1.6$ & $33.4 \pm 1.6$ & $105.6 \pm 4.9$ & $99.9 \pm 5.0$ \\
Şebin & $38.2 \pm 1.8 \mathrm{~h}$ & Maraş-18 & $33.7 \pm 2.5 \mathrm{j}$ & $30.3 \pm 2.3$ & $34.4 \pm 2.5$ & $113.6 \pm 8.2$ & $101.6 \pm 7.6$ \\
Pedro & $39.0 \pm 2.7 \mathrm{~g}$ & Midland & $34.4 \pm 2.4 \mathrm{i}$ & $30.7 \pm 2.1$ & $35.3 \pm 1.7$ & $116.2 \pm 8.1$ & $103.3 \pm 6.8$ \\
Howard & $39.7 \pm 1.6 \mathrm{f}$ & Bilecik & $34.7 \pm 1.5 \mathrm{hi}$ & $30.7 \pm 1.3$ & $35.0 \pm 1.3$ & $111.8 \pm 4.5$ & $103.7 \pm 4.0$ \\
Maraş-18 & $39.8 \pm 2.9 \mathrm{f}$ & Pedro & $35.0 \pm 2.1 \mathrm{gh}$ & $31.3 \pm 2.2$ & $34.9 \pm 2.2$ & $112.0 \pm 7.1$ & $104.8 \pm 6.6$ \\
Bilecik & $40.1 \pm 1.8 \mathrm{ef}$ & Sütyemez-2 & $35.1 \pm 1.7 \mathrm{gh}$ & $30.9 \pm 1.5$ & $35.8 \pm 1.7$ & $120.7 \pm 5.5$ & $105.0 \pm 4.8$ \\
Serr & $40.3 \pm 2.4 \mathrm{ef}$ & Şebin & $35.5 \pm 1.9 \mathrm{fg}$ & $32.0 \pm 1.7$ & $35.1 \pm 1.7$ & $115.1 \pm 5.6$ & $106.8 \pm 5.3$ \\
Kaman-5 & $40.6 \pm 2.0 \mathrm{de}$ & Howard & $35.7 \pm 1.4 \mathrm{ef}$ & $32.0 \pm 1.0$ & $35.7 \pm 1.1$ & $114.8 \pm 3.4$ & $107.2 \pm 3.3$ \\
Chandler & $41.0 \pm 1.9 \mathrm{~d}$ & Chandler & $36.0 \pm 1.6 \mathrm{e}$ & $32.7 \pm 1.4$ & $36.4 \pm 1.5$ & $118.7 \pm 4.7$ & $108.9 \pm 4.5$ \\
Midland & $41.8 \pm 3.2 \mathrm{c}$ & Şen-2 & $37.3 \pm 1.7 \mathrm{~d}$ & $32.9 \pm 1.2$ & $37.9 \pm 1.4$ & $123.3 \pm 4.8$ & $111.2 \pm 4.1$ \\
Sütyemez-2 & $42.5 \pm 2.1 \mathrm{~b}$ & Sütyemez-1 & $38.0 \pm 2.1 \mathrm{c}$ & $33.7 \pm 1.9$ & $36.3 \pm 1.9$ & $112.9 \pm 5.8$ & $113.7 \pm 6.0$ \\
Şen-2 & $44.2 \pm 2.0 \mathrm{a}$ & Kaman-5 & $39.7 \pm 1.8 \mathrm{~b}$ & $35.7 \pm 1.8$ & $38.6 \pm 1.7$ & $122.8 \pm 5.7$ & $120.0 \pm 5.6$ \\
KR-1 & $44.3 \pm 2.6 \mathrm{a}$ & KR-1 & $45.1 \pm 2.5 \mathrm{a}$ & $40.0 \pm 2.2$ & $43.1 \pm 2.3$ & $132.9 \pm 7.4$ & $134.7 \pm 7.4$ \\
\hline Mean \pm SD & $40.2 \pm 3.2$ & Mean \pm SD & $35.8 \pm 3.7$ & $32.0 \pm 3.2$ & $35.8 \pm 3.0$ & $115.7 \pm 9.1$ & $107.6 \pm 10.7$ \\
Range & $(30.4-51.3)$ & Range & $(25.6-53.3)$ & $(23.5-45.5)$ & $(26.8-49.6)$ & $(89.0-152.9)$ & $(78.3-155.0)$ \\
F $(P$, sigma $)$ & $102.86(0.000)^{* *}$ & F $(P$, sigma $)$ & $294.37(0.000)^{* *}$ & & & & \\
\hline
\end{tabular}

* one hundred repetitive means $(n=100)$ for each cultivar followed by the same letter in the same column are not different as determined by the Tukey test at $5 \%$ significance level

$* *$ highly significant $(p<0.01)$

the KR-1 cultivar also had considerably higher averages in terms of width, thickness, geometric mean diameter and perimeter. In any case, the lowest width and thickness values were observed for the Maraş-12 and Serr cultivars.

\subsection{Shape attributes describing walnut cultivars}

The walnut cultivar KR-1 had the closest shape to a sphere with a sphericity average of $96.7 \%$ (Table 6). The shape of Serr, Sütyemez-2, Midland and Sen-2 cultivars were described as oval because their shape index average was greater than 1.25, and their sphericity averages ranged between $82.6 \%$ and $85.7 \%$. While the aspect ratios determined at the horizontal orientation of the walnuts which had a high sphericity average were low in general; the averages at the vertical orientation varied, regardless of the horizontal orientation.

\subsection{Results of cluster analysis based on dimensional and shape attributes}

As seen in Figure 2, the hierarchical cluster analysis divided the walnut cultivars into two main groups. The first main group had two subgroups (shown with green triangle). While the $1^{\text {st }}$ subgroup was composed of two clusters (cluster 1 and cluster 2), the $2^{\text {nd }}$ subgroup constituted cluster 3 . The second main group consisted of a single walnut cultivar comprised of cluster 4. Consequently, cluster 1 involved six walnut cultivars (Howard, Sebin, Pedro, Bilecik, Midland and Maras-18), similar to each other with regard to size and descriptive shape attributes. The Maraş12, Kaman-1 and Serr cultivars were in cluster 2. Cluster 3 had five walnut cultivars (Chandler, Sen2, Sütyemez-2, Sütyemez-1 and Kaman-5). KR-1, due to different size and descriptive attributes, was grouped separately into the $4^{\text {th }}$ cluster.

\subsection{Shape distinction based on Elliptic Fourier Analysis}

The Elliptic Fourier analysis (EFA) revealed that the first seven variables shown in Figure 3 explained $92.7 \%$ of the total variance. The corresponding principle components PC1, PC2, PC3, PC4, PC5, PC6 and PC7 constituted 65.3\%, 11.9\%, 5.1\%, $4.1 \%, 2.6 \%, 2.1 \%$ and $1.6 \%$ of the total variation, respectively. Each significant principle component (PC) was derived from the chain codes of the walnut contours illustrated, regardless of the shape variation in the cultivars. PC1 was the component which explained the greatest variation among the walnut 
TABLE 6. Sphericity, shape index and aspect ratio attributes

\begin{tabular}{|c|c|c|c|c|c|c|c|}
\hline Cultivars & $\begin{array}{c}\text { Sphericity } \\
(S, \%)\end{array}$ & $\begin{array}{c}\text { Shape } \\
\text { Index }(S I)\end{array}$ & $\begin{array}{l}\text { Shape } \\
\text { description }\end{array}$ & Cultivars & $\begin{array}{c}\text { Aspect ratio at } \\
\text { horiz. orient. } \\
\left(A R_{h}\right)\end{array}$ & Cultivars & $\begin{array}{c}\text { Aspect ratio at } \\
\text { vertical orient. } \\
\left(A R_{v}\right)\end{array}$ \\
\hline Serr & $82.55 \pm 2.53 \mathrm{k}^{*}$ & $1.333 \pm 0.060$ & Oval & Kaman-5 & $1.071 \pm 0.036 \mathrm{j}$ & Şebin & $1.054 \pm 0.032 \mathrm{e}$ \\
\hline Sütyemez-2 & $84.44 \pm 1.92 \mathrm{i}$ & $1.287 \pm 0.044$ & Oval & Şebin & $1.072 \pm 0.037 \mathrm{j}$ & Maraş-18 & $1.067 \pm 0.032 \mathrm{~d}$ \\
\hline Midland & $84.79 \pm 6.05 \mathrm{i}$ & $1.292 \pm 0.138$ & Oval & Sütyemez-1 & $1.078 \pm 0.050 \mathrm{ij}$ & Sütyemez-2 & $1.068 \pm 0.034 \mathrm{~d}$ \\
\hline Şen-2 & $85.70 \pm 1.85 \mathrm{~h}$ & $1.259 \pm 0.041$ & Oval & KR-1 & $1.090 \pm 0.036 \mathrm{i}$ & Chandler & $1.073 \pm 0.032 \mathrm{~d}$ \\
\hline Maraş-18 & $86.41 \pm 2.40 \mathrm{~h}$ & $1.245 \pm 0.052$ & Spherical & Howard & $1.175 \pm 0.051 \mathrm{~h}$ & Maraş-12 & $1.097 \pm 0.030 \mathrm{c}$ \\
\hline Bilecik & $87.20 \pm 2.19 \mathrm{~g}$ & $1.227 \pm 0.047$ & Spherical & Chandler & $1.179 \pm 0.044 \mathrm{fg}$ & Kaman-1 & $1.098 \pm 0.040 \mathrm{c}$ \\
\hline Maraş-12 & $88.59 \pm 2.11 \mathrm{f}$ & $1.199 \pm 0.043$ & Spherical & Maraş-12 & $1.190 \pm 0.042 \mathrm{ef}$ & Midland & $1.100 \pm 0.044 \mathrm{c}$ \\
\hline Chandler & $88.79 \pm 1.98 \mathrm{f}$ & $1.195 \pm 0.040$ & Spherical & Maraş-18 & $1.191 \pm 0.047 \mathrm{ef}$ & Kaman-5 & $1.101 \pm 0.040 \mathrm{c}$ \\
\hline Kaman-1 & $89.03 \pm 2.18 \mathrm{ef}$ & $1.190 \pm 0.043$ & Spherical & Kaman-1 & $1.198 \pm 0.046 \mathrm{e}$ & Serr & $1.103 \pm 0.039 \mathrm{c}$ \\
\hline Pedro & $89.62 \pm 2.34 \mathrm{de}$ & $1.179 \pm 0.042$ & Spherical & Pedro & $1.201 \pm 0.049 \mathrm{e}$ & Howard & $1.106 \pm 0.038 \mathrm{c}$ \\
\hline Howard & $89.93 \pm 1.95 \mathrm{~d}$ & $1.172 \pm 0.039$ & Spherical & Sütyemez-2 & $1.220 \pm 0.041 \mathrm{~d}$ & Pedro & $1.117 \pm 0.038 b$ \\
\hline Şebin & $92.03 \pm 1.90 \mathrm{c}$ & $1.132 \pm 0.035$ & Spherical & Bilecik & $1.250 \pm 0.045 \mathrm{c}$ & KR-1 & $1.128 \pm 0.038 \mathrm{ab}$ \\
\hline Kaman-5 & $95.01 \pm 2.10 \mathrm{~b}$ & $1.087 \pm 0.030$ & Spherical & Midland & $1.273 \pm 0.050 \mathrm{~b}$ & Bilecik & $1.128 \pm 0.047 \mathrm{ab}$ \\
\hline Sütyemez-1 & $95.62 \pm 2.95 b$ & $1.095 \pm 0.033$ & Spherical & Şen-2 & $1.282 \pm 0.044 \mathrm{~b}$ & Sütyemez-1 & $1.129 \pm 0.041 \mathrm{a}$ \\
\hline KR-1 & $96.87 \pm 1.52 \mathrm{a}$ & $1.076 \pm 0.021$ & Spherical & Serr & $1.295 \pm 0.056 \mathrm{a}$ & Şen-2 & $1.136 \pm 0.042 \mathrm{a}$ \\
\hline Mean \pm SD & $89.07 \pm 4.85$ & $1.198 \pm 0.092$ & - & Mean \pm SD & $1.185 \pm 0.086$ & Mean \pm SD & $1.100 \pm 0.045$ \\
\hline Range & $69.75-99.99$ & $1.029-1.715$ & - & Range & $1.000-1.440$ & Range & $1.003-1.268$ \\
\hline $\mathrm{F}(P$, sigma $)$ & $262.25(0.000)^{* *}$ & & & $\mathrm{~F}(P$, sigma $)$ & $280.86(0.000)^{* *}$ & $\mathrm{~F}(P$, sigma $)$ & $44.40(0.000)^{* *}$ \\
\hline
\end{tabular}

* one hundred repetitive means $(n=100)$ for each cultivar followed by the same letter in the same column are not different as determined by the Tukey test at $5 \%$ significance level

$* *$ highly significant $(p<0.01)$

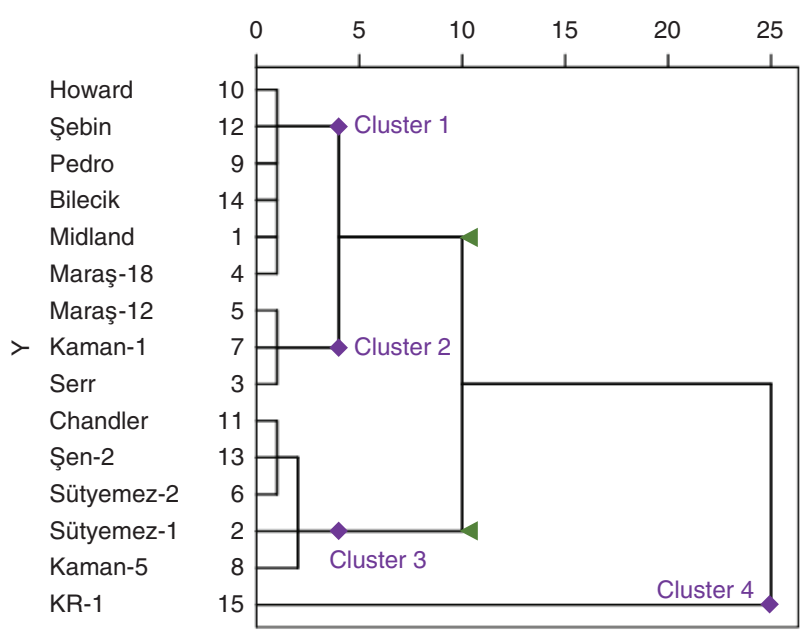

Figure 2. Dendrogram of the walnut cultivars

cultivars and showed the width alteration in the walnut cultivars. This alteration resulted in a variation in dimensional and shape attributes such as length, sphericity and aspect ratio. The principle components PC2 - PC7 described the smaller variations in the outlines of the walnut cultivars. For instance, PC2 originated from the swelling of the walnut base.
Flatness and tapering at the bottom of the walnut was revealed by PC3. There was a one-sided tapering at the bottom of the walnut at PC4. At PC5, the slight, centripetal tapering was found at the walnut base. At PC6, tapering and flatness form both the top and the bottom of the walnut were determined. PC7, which was the lowest component of total variance, constituted the reason for the flatness at the bottom and tapering at the top of the walnut.

\subsection{Results of discriminant analysis based on Elliptic Fourier descriptors and pairwise comparison in shape}

According to results from the discriminant analysis illustrated in Table 7, six canonical discriminant functions were obtained from the significant principle components (PC1-PC7) derived from EFA based on walnut outlines. Discriminant analysis showed that the first seven PC scores explained a major part of the variance among the PCs. The first two canonical functions explained $86.9 \%$ of the total variance. In reference to the Wilk's Lambda and Pillai Trace statistics, significant differences were observed in the shapes of the walnut cultivars. The Hotelling's pairwise comparison results revealed the distinctions and showed similarities among the outlines of the walnut cultivars. Mahalanobis 


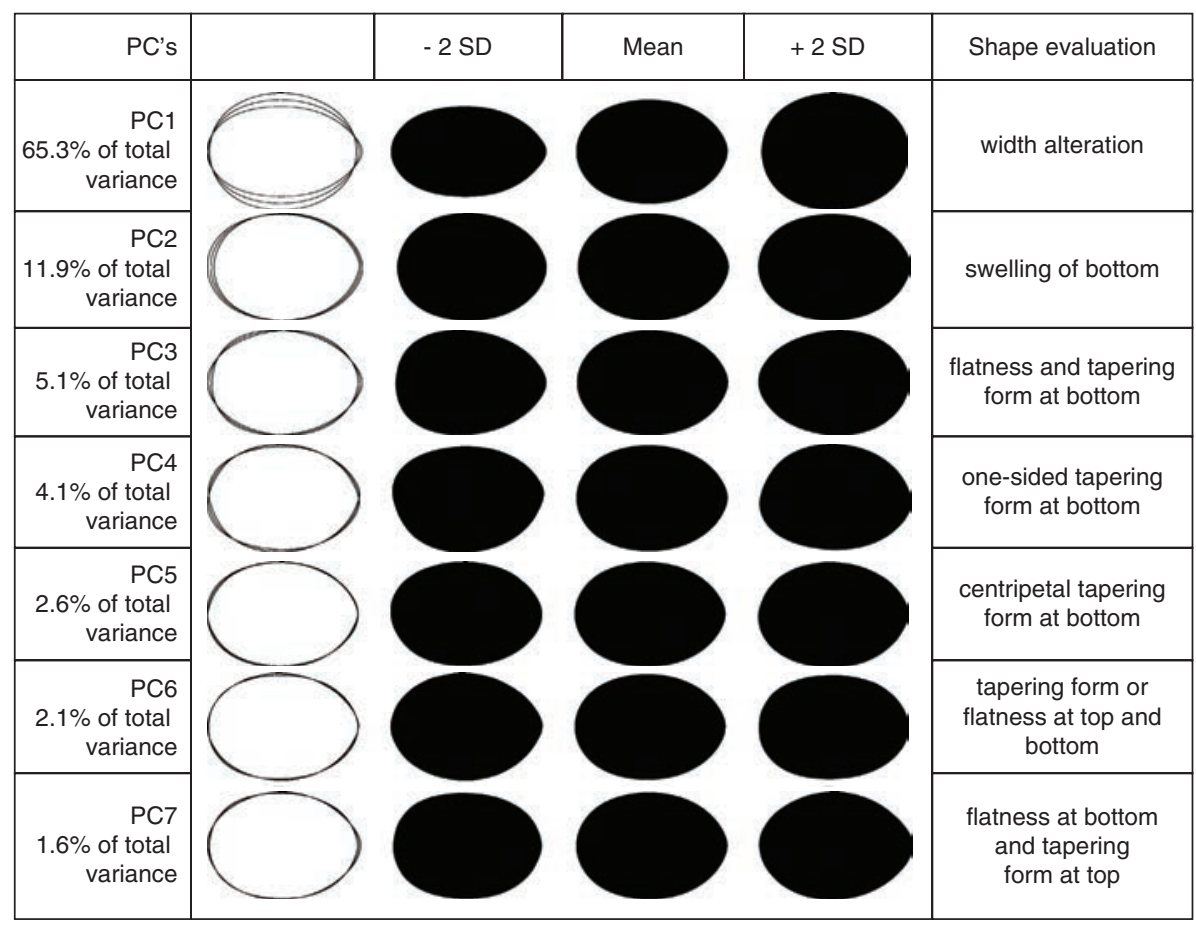

FIGURE 3. Principal components (PCs) of the walnut cultivars

distances in the lower triangle account for the variance of each walnut outline and the covariance between the cultivars. As the distance increased, the distinctions among the cultivars grew. The lowest distances marked in the lower triangle showed the cultivars which were similar to each other. Bonferroni-corrected $\mathrm{P}$ values were given in the upper triangle and the walnut cultivars which were identical were colored as pairwise. The uncolored cells showed the significant $(p<0.01$ and $p<0.05)$ distinctions among the pairwise walnut cultivars.

The results of the Hotelling's pairwise comparisons were found to be compatible with the scatter plot shown in Figure 4. The scatter plot showed the cultivar centroids with regard to their canonical discriminant functions. The loadings of the first two canonical functions explained $86.9 \%$ of the total variance and they were presented as standardized canonical discriminant function coefficients in Table 7. According to these loadings, the canonical function 1 had the highest loading of the PC1, while the canonical function 2 explained the variation caused by PC3, PC6 and PC7. The similarities or distinctions among the cultivars should be evaluated based on the results of the Hotelling's pairwise comparison in addition to the centroids in the scatter plot. Because Kaman-5 had a different characteristic in shape, it remained alone in its own group. The centroid coordinates shown in Figure 4 indicated that the Howard and Maraş-12 cultivars had different shape attributes, because their coordinates on the function 2 axis were different. However, their coordinates were close to the origin of the discriminant function 1 axis, and the results of the pairwise comparison test determined the similarity between them. Serr and Midland were the cultivars which comparatively stayed on the left of the function 1 axis. Chandler, Pedro, Kaman-1 and Maraş-18 were similar cultivars in shape due to their centralizing at the origin. Sütyemez-2, Bilecik and Şen-2 cultivars together constituted a separate group in shape attributes.

\section{DISCUSSION}

The surface area attribute of agricultural products is closely related to evaporation. Hence, Mohseni and Peters (2016) reported that an increasing ratio of $360 \%$ at the surface area of a particle caused the drying rate to be enhanced by more than twice. George et al., (2007) reported that the drying rate was accelerated due to increased surface area of the product and recommended a surface area to volume ratio of $12 \mathrm{~cm}^{-1}$ for the optimal ratio of surface area to volume for thin-layer drying of breadfruit with sun drying. Dursun (2001) indicated that the projected area of a product is a crucial engineering parameter for classification and clearing with regard to the principles of hydrodynamic and aerodynamic. Sayınc1 et al., (2015a) determined that the projected area average of 


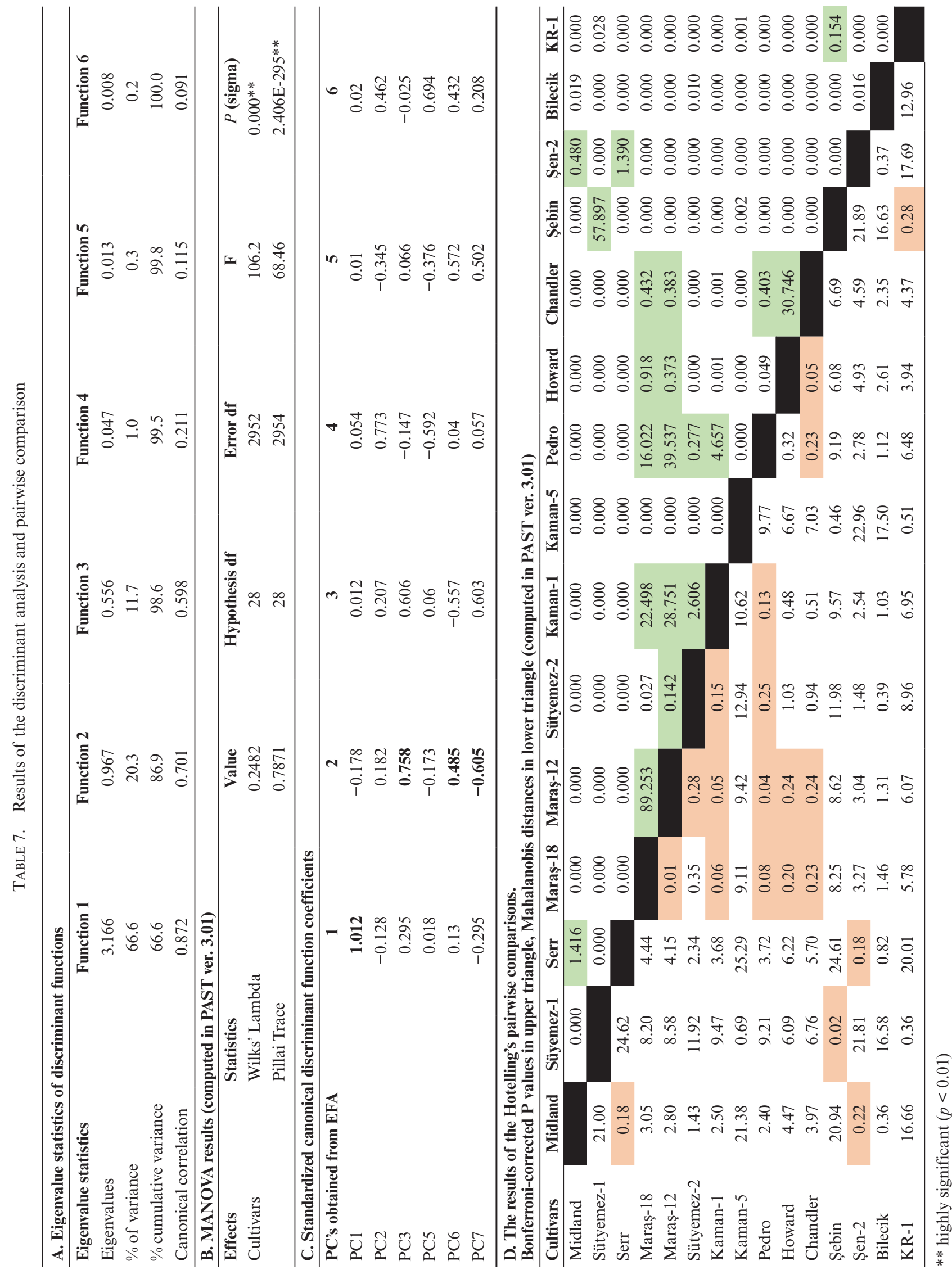




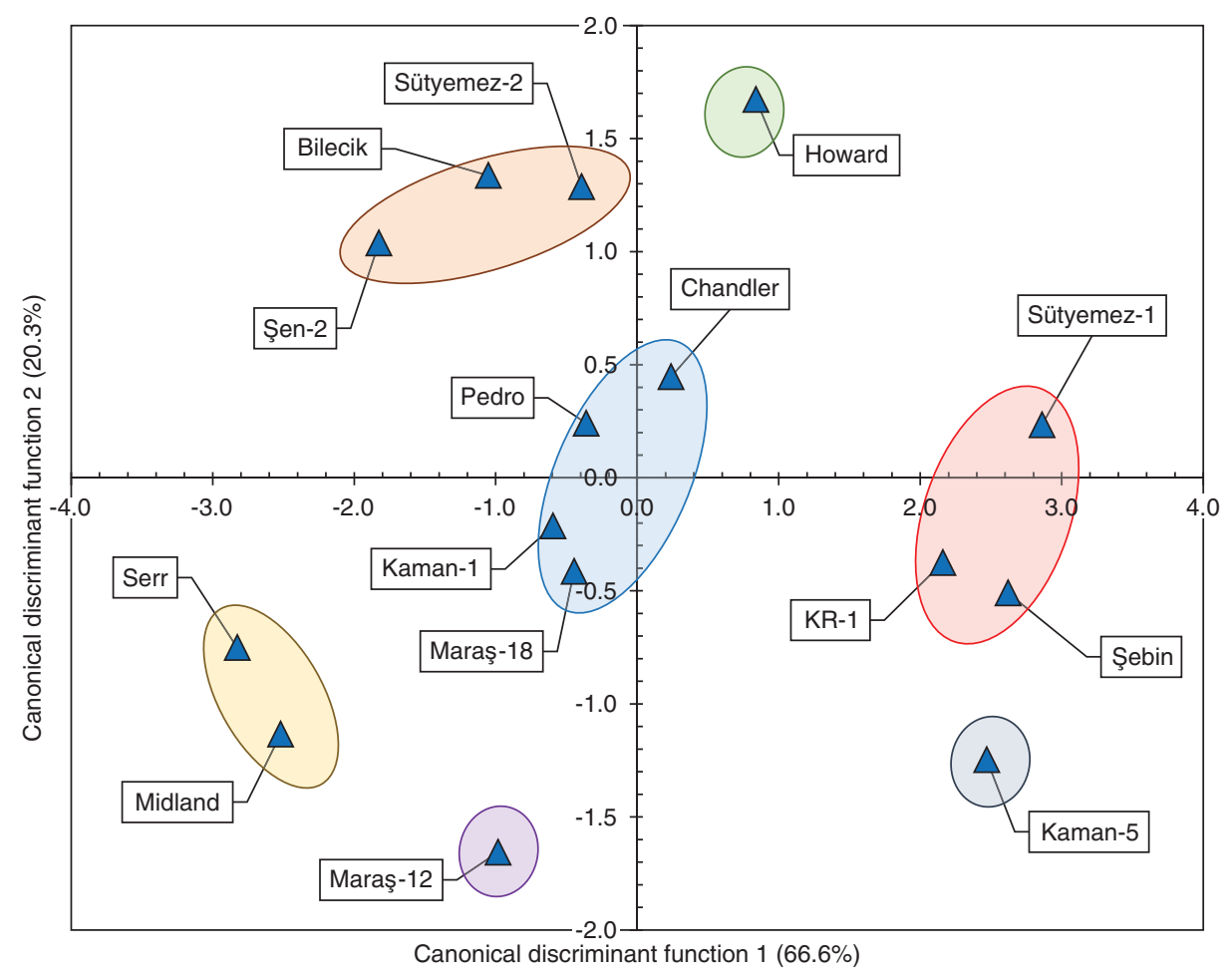

FIGURE 4. Group centroids of the walnut cultivars

hazelnut cultivars was to be $2.69 \mathrm{~cm}^{2}$. This average showed that the projected area average of $10.5 \mathrm{~cm}^{2}$ of the walnut cultivars used in present study were 3.9-fold higher than that of the hazelnut cultivars.

In a study conducted by Ercisli et al., (2012), the variation interval of the dimensional averages for walnut cultivars were determined as between $40.5-48.8 \mathrm{~mm}$ for length, between $34.0-46.4 \mathrm{~mm}$ for width and between $32.0-42.7 \mathrm{~mm}$ for thickness. For the walnut cultivars used in present study, the length, width and thickness averages varied between $37.6-44.3 \mathrm{~mm}$, between $32.1-45.1 \mathrm{~mm}$, and between 28.3-40.0 mm, respectively. These dimensional attributes are crucial engineering parameters for walnut cracking systems and separation, and used to adjust the dimensions between cylinder pairs in breaker systems designed to crack walnut shells. Similarly, the pore dimensions for the separation processing of the walnut cultivars should be determined by taking dimensional attributes into account.

Aspect ratio is defined by the major axis and minor axis of an ellipse equivalent to an object. Aspect ratios close to 1 indicate increasing circularity of the object on a two dimensional view. But, in the present study, decreasing sphericity was observed with increasing aspect ratios. Such a finding indicates that the relation between aspect ratio and sphericity or shape index was insignificant. According to the shape description, it can be concluded that most of the walnut cultivars were spherical-shaped. The studies conducted on walnut cultivars or genotypes by Ercisli et al., (2012) and Ozkan and Koyuncu (2005) support the present findings. While shape index average decreased, the sphericity of the walnuts increased because the relation between both variables was significant.

Sayinc1 et al., (2015a) noted that the EFA method provided a superior distinction among hazelnut cultivars. The size and shape attributes of the walnut cultivars were quite well distinguished with the EFA method in the present study. Cluster analysis is also an easy method used to distinguish cultivars. Cluster analysis revealed similar walnut cultivars. All these findings provide crucial information for walnut processing technologies such as cracking, separation, cleaning, packaging and transporting.

Shape distinctions for walnut cultivars originates predominantly from width alteration. The other significant distinctions among the cultivars were the swelling, flatness or tapering form of the walnut base. These typical distinctions can be beneficial to distinguish the cultivars, to determine the abnormality or quality of the product, and to design separators for product classification processes.

\section{CONCLUSIONS}

In the present study, walnut shapes were analyzed with the EFA method through closed-counter modelling of the products and the method revealed 
distinctions among the walnut cultivars quite well. Both the centroid distributions on scatter plot and pairwise comparisons revealed similarities among them and allowed for classifying the walnut cultivars.

\section{ACKNOWLEDGMENTS}

The authors are grateful to Prof. Dr. Yücel ERKMEN, head of Department of Agricultural Machinery and Technologies Engineering of Agricultural Faculty at Atatürk University for providing laboratory resources. The authors are also grateful to Assoc. Prof. Dr. Zeki Gökalp (a Certified English Translator and an expert in Biosystems Engineering) for his critical reading and through syntactic corrections of the manuscript.

\section{REFERENCES}

Antonucci F, Costa C, Pallottino F, Paglia G, Rimatori V, De Giorgio D, Menesatti P. 2012. Quantitative method for shape description of almond cultivars (Prunus amygdalus Batsch). Food Bioprocess Technol. 58, 768-785. https://doi. org/10.1007/s11947-010-0389-2

Bayazit S, Kazan K, Gulbitti S, Cevik V, Ayanoglu H, Ergul A. 2007. AFLP analysis of genetic diversity in low chill requiring walnut (Juglans regia L.) genotypes from Hatay, Turkey. Sci. Hortic. 111, 394-398. https://doi.org/10.1016/j. scienta.2006.11.006

Boydas MG, Sayinci B, Gozlekci S, Oztürk I, Ercisli S. 2012. Basic physical properties of fruits in loquat (Eriobotrya Japonica (Thunb. Lindl.) cultivars and genotypes determined by both classical method and digital image processing. Afr. J. Agric. Res. 7, 4171-4181.

Brewer MT, Moyseenko JB, Monforte AJ, Van Der Knaap E. 2007. Morphological variation in tomato: a comprehensive study of quantitative trait loci controlling fruit shape and development. J. Exp. Bot. 58, 1339-1349. https://doi.org/ $10.1093 / \mathrm{jxb} / \mathrm{erl} 301$

Cosmulescu S, Baciu A, Achim G, Botu M. Trandafir I. 2009. Mineral composition of fruits in different walnut (Juglans regia L.) cultivars. Not. Bot. Hort. Agrobot. Cluj. 37, $156-160$.

Costa C, Antonucci F, Pallottino F, Aguzzi J, Sun DW, Menesatti P. 2011. Shape analysis of agricultural products: a review of recent research advances and potential application to computer vision. Food Bioprocess Technol. 4, 673-692. https://doi.org/10.1007/s11947-011-0556-0

Costa C, Menesatti P, Paglia G, Pallottino F, Aguzzi J, Rimatori V, Russo G, Recupero S, Recupero GR. 2009. Quantitative evaluation of Tarocco sweet orange fruit shape using optoelectronic Elliptic Fourier based analysis. Postharvest Biol. Tec. 54, 38-47. https://doi.org/10.1016/j. postharvbio.2009.05.001

Currie AJ, Ganeshanandam S, Noiton DA, Garrick D, Shelbourne CJA, Orgaguzie N. 2000. Quantitative evaluation of apple (Malus domestica Borkh.) fruit shape by principal component analysis of Fourier descriptors. Euphytica 111, 219-227.

Dursun İG. 2001. Bazı taneli ürünlerin izdüșüm alanlarının görüntü işlemeyle belirlenmesi. Tarım Bilim. Derg. 7, 102-107.

Ercisli S, Sayinci B, Kara M, Yildiz C, Ozturk I. 2012. Determination of size and shape features of walnut (Juglans regia L.) cultivars using image processing. Sci. Hortic. 133, 47-55. https://doi.org/10.1016/j.scienta.2011.10.014
FAO (2014). Crops data statistics. http://www.fao.org/faostat/ en/\#data/OC - Production. Crops (accessed 05.12.2017).

George C, McGruder R, Torgerson K. 2007. Determination of optimal surface area to volume ratio for thin-layer drying of breadfruit (Artocarpus altilis). Int. J. Service Learn. Eng. 2, 76-88.

Ghazanfari A, Irudayaraj J, Kusalik A, Romaniuk M. 1997. Machine vision grading of pistachio nuts using Fourier descriptors. J. Agr. Eng. Res. 68, 247-252. https://doi.org/ 10.1006/jaer.1997.0205

Hammer Ø, Harper DAT, Ryan PD. 2001. PAST: Paleontological statistics software package for education and data analysis. Palaeontol. Electron. 4, 1-9.

Iwata H, Ukai Y. 2002. SHAPE: A computer program package for quantitative evaluation of biological shapes based on Elliptic Fourier descriptors. J. Hered. 93, 384-385. https:// doi.org/10.1093/jhered/93.5.384

Kara M, Sayıncı B, Elkoca E, Öztürk İ, Özmen TB. 2013. Seed size and shape analysis of registered common bean (Phaseolus vulgaris L.) cultivars in Turkey using digital photography. Tartm Bilim. Derg. 19, 219-234.

Liming X, Yanchao Z. 2010. Automated strawberry grading system based on image processing. Comput. Electron. Agr. 71, 32-39. https://doi.org/10.1016/j.compag.2009.09.013

Mebatsion HK, Paliwal J, Jayas DS. 2012. Evaluation of variations in the shape of grain types using principal components analysis of the elliptic Fourier descriptors. Comput. Electron. Agr. 80, 63-70. https://doi.org/10.1016/j.compag. 2011.10 .016

Mohseni M, Peters B. 2016. Surface area effects on particulate drying in a rotary dryer. $12^{\text {th }}$ International Conference on Heat Transfer, Fluid Mechanics and Thermodynamics. 11 to 13 July, Spain.

Mohsenin NN. 1986. Physical properties of plant and animal materials. New York, Gordon and Breach Science Publisher

Ozkan G, Koyuncu MA. 2005. Physical and chemical composition of some walnut (Juglans regia L.) genotypes grown in Turkey. Grasas Aceites 56, 141-146. https://doi.org/10.3989/ gya. 2005.v56.i2.122

Patel G. 2005. Essential fats in walnuts are good for the heart and diabetes. J. American Dietetic Assoc. 105, 1096-1097. https://doi.org/10.1016/j.jada.2005.05.193

Sadrnia H, Rajabipour A, Jafary A, Javadi A, Mostofi Y. 2007. Classification and analysis of fruit shapes in long type watermelon using image processing. Int. J. Agr. Biol. 9, 68-70.

Şahin İ, Akbaş H. 2001. Farklı yöre ve çeşitlerden cevizlerin teknolojik özelliklerinin araștırılması. Türkiye I. Ulusal Ceviz Sempozyumu, 5-8 Eylül 2001, Tokat, 104-114. (in Turkish)

Sayinci B, Ercisli S, Ozturk I, Eryilmaz Z, Demir B. 2012. Determination of size and shape in the 'Moro' blood orange and 'Valencia' sweet orange cultivar and its mutants using image processing. Not. Bot. Horti. Agrobo. 40, 234 242. https://doi.org/10.15835/nbha4016645

Sayıncı B, Kara M, Ercişli S, Duyar Ö, Ertürk Y. 2015a. Elliptic Fourier analysis for shape distinction of Turkish hazelnut cultivars. Erwerbs-Obstbau. 57, 1-11. https://doi.org/ 10.1007/s10341-014-0221-7

Sayıncı B, Ercisli S, Akbulut M, Savsatlı Y, Baykal H. 2015b. Determination of shape in fruits of cherry laurel (Prunus laurocerasus) accessions by using Elliptic Fourier analysis. Acta Sci. Pol. Hortoru. 14, 63-82.

Sen SM, Tekintas FE. 1992. A study on the selection of Adilcevaz walnuts. Acta Hortic. 317, 171-174. https://doi.org/10.17660/ ActaHortic.1992.317.19

Sun D, Costa C, Menesatti P. 2012. Advantages of using quantitative shape descriptors in protocols for plant cultivar and postharvest product quality assessment. Food Bioprocess Technol. 5, 1-2. https://doi.org/10.1007/s11947-011-0715-3

Vasallo EGR, Torres MAJ, Demayo CD. 2013. Elliptic Fourier analysis in describing scutes in selected body Regions of Decapterus sp. Int. J. Biosci. Biochem. Bioinforma. 3, 411-415. 